\title{
EKSPANSI PERKEBUNAN KELAPA SAWIT DAN PERUBAHAN SOSIAL EKOLOGI PEDESAAN
}

\section{The Expansion of Palm Oil Plantation and Changes of Rural Social Ecology}

\author{
Nursantri Hidayah), Arya Hadi Dharmawan, dan Baba Barus \\ Program Studi Ilmu Perencanaan Pembangunan Wilayah dan Perdesaan, Institut Pertanian Bogor
}

${ }^{*}$ E-mail: nursant@gmail.com

\begin{abstract}
The biggest threat to Indonesian forest is the rise of new palm oil plantation. Indonesia ranked the top by the quantity and rate of expansion of oil palm cultivation. Riau ranked first with a contribution of 29 percent of the total national production of palm oil. The rate of expansion of oil palm plantations such as by land use change forest area, land of community, and farmland. Demand for land to the expansion of oil palm plantations in Riau Province continues to increase is so that has triggered high rates of conversion of land into oil palm plantations, this expansion HAS ALSO led to a conservation area. Many cases of illegal land conversion is done as occurs in protected areas and conservation. Tesso Nilo National Park is one of the National Park in Riau province precisely in Pelalawan and Indragiri Hulu does not escape from the activity of land conversion for oil palm plantations. Oil palm expansion has led to various effects such as changes in the landscape, the relocation of land and natural resources, changing economic and social. This research was conducted with the aim of identifying changes in land use landscape surrounding Tesso Nilo National Park, the changes livelihoods of local communities and the vulnerability of farm Households. Studies conducted in the village conservation area affected by oil palm expansion. Data were Analyzed descriptively by using spatial analysis and livelihood systems. From the results of the research Noted that oil palm expansion in Tesso Nilo has the caused massive degraded forests, forest cover is left now only about 20 percent. The pattern of the community living around the area turn out to be are relatively homogeneous with one source of income is from oil palm plantations. This causes people to be vulnerable to a crisis when palm oil prices declined. The high food consumption from the dependent communities will complicate the supply from outside the community when revenues decline. For the sustainability of the region need more intensive management area so that the destruction of the forests as a result of actions of this expansion can be overcome and potential conflicts between the oil palm and food crops in the future must be anticipated so there is no economic vulnerability of farm households.
\end{abstract}

Keywords: ecology landscape changes, expansion of oil palm, livelihood systems

\begin{abstract}
ABSTRAK
Ancaman terbesar terhadap hutan Indonesia adalah maraknya pembukaan perkebunan kelapa sawit baru. Indonesia menduduki peringkat teratas berdasarkan kuantitas perluasan perkebunan dan laju penanaman kelapa sawit. Riau berada di peringkat pertama dengan kontribusi sebesar 29 persen terhadap total produksi minyak sawit nasional.Laju perluasan perkebunan kelapa sawit diantaranya dengan jalan mengalihfungsikan kawasan hutan, kebun rakyat, dan lahan pertanian. Permintaan lahan untuk ekspansi perkebunan sawit di Provinsi Riau terus meningkat sehingga telah memicu tingginya angka konversi lahan menjadi perkebunan kelapa sawit, ekspansi ini juga sudah mengarah ke kawasan konservasi. Banyak kasus konversi lahan dilakukan secara illegal seperti yang terjadi pada kawasan lindung dan konservasi. Taman Nasional Tesso Nilo (TNTN) adalah salah satu Taman Nasional di Provinsi Riau tepatnya di Kabupaten Pelalawan dan Kabupaten Indragiri Hulu yang tidak luput dari aktivitas konversi lahan untuk perkebunan kelapa sawit. Ekspansi kelapa sawit telah menimbulkan berbagai dampak seperti terjadinya perubahan bentang alam, relokasi tanah dan sumber daya alam, perubahan ekonomi dan perubahan sosial. Penelitian ini dilakukan dengan tujuan mengidentifikasi perubahan penggunaan lahan disekitar lanskap Taman Nasional Tesso Nilo, perubahan sistem naflah masyarakat lokal dan kerentanan rumah tangga petani. Studi dilakukan di desa sekitar kawasan konservasi yang terkena dampak ekspansi kelapa sawit. Data dianalisis secara deskriptif dengan menggunakan analisis spasial dan analisis sistem penghidupan. Dari hasil penelitan diketahui bahwa ekspansi kelapa sawit di sekitar Taman Nasional Tesso Nilo telah menyebabkan hutan terdegradasi secara masif, tutupan hutan yang tersisa saat ini hanya sekitar 20 persen. Pola nafkah masyarakat sekitar kawasan berubah menjadi cenderung homogen dengan satu sumber nafkah yaitu dari perkebunan kelapa sawit. Ini menyebabkan masyarakat menjadi rentan terhadap krisis ketika harga kelapa sawit menurun. Tingginya konsumsi pangan masyarakat yang tergantung pasokan dari luar akan menyulitkan masyarakat ketika pendapatan mengalami penurunan.Bagi keberlanjutan pengembangan wilayah perlunya pengelolaan kawasan yang lebih intensif sehingga kerusakan hutan akibat tindakan ekspansi ini bisa diatasi dan potensi konflik antara pihak perkebunan kelapa sawit dan pertanian tanaman pangan kedepan harus diantisipasi sehingga tidak terjadi kerentanan ekonomi rumah tangga petani.
\end{abstract}

Kata kunci: perubahan lanskap ekologi, ekspansi kelapa sawit, sistem penghidupan

\section{PENDAHULUAN}

Konsumsi produk yang mengandung minyak sawit selama beberapa dekade terakhir terus mengalami peningkatan. Permintaan global untuk minyak sawit diperkirakan naik dua kali lipat pada tahun 2020 dengan tingkat kenaikan diperkirakan mendekati 4 persen per tahun. Saat ini kelapa sawit merupakan perdagangan minyak nabati terbesar di dunia, mencapai sekitar 40 persen dari total perdagangan minyak nabati dunia, sekitar dua kali lipat dari minyak kedelaiyang berada pada posisi 
kedua. Sejaktahun 1990-an, permintaan Eropa Barat untuk produk minyak sawit telah mulai stabil, sementara permintaan dari India, Pakistan, Cina dan Timur Tengah meningkat tajam dan merupakan pasar baru, demikian juga pasar di Eropa Timur semakin meningkat. Pertumbuhan yang begitu tinggi di pasar minyak kelapa sawit menjadi pemicu utama ekspansi kelapa sawit di Asia Tenggara. (Colchester, 2007).

Salah satu bentuk ancaman terbaru terhadap hutan Indonesia adalah maraknya pembukaan perkebunan kelapa sawit baru. Indonesia saat ini menduduki peringkat teratas berdasarkan kuantitas perluasan perkebunan dan laju penanaman kelapa sawit. Peringkat ini telah mendudukan Indonesia sebagai produsen sawit nomor satu didunia diikuti oleh Malaysia. Sentra utama kelapa sawit Indonesia (dalam wujud minya sawit) pada tahun 2011 terdapat di 5 (lima) Propinsi, yaitu Riau, Sumatra Utara, Kalimantan Tengah, Sumatera Selatan dan Jambi. Riau berada di peringkat pertama dengan kontribusi sebesar 28,96 persen terhadap total produksi minya sawit nasional, sedangkan propinsi lain memberikan kontribusi kurang dari 15 persen (Pusdatin Deptan,2013).

Permintaan lahan untuk ekspansi perkebunan sawit di Provinsi Riau terus meningkat sehingga telah memicu tingginya angka konversi lahan menjadi perkebunan kelapa sawit, bahkan banyak kasus konversi lahan dilakukan secara illegal seperti yang terjadi pada kawasan lindung dan konservasi. Taman Nasional Tesso Nilo (TNTN) adalah salah satu Taman Nasional di Provinsi Riau tepatnya di Kabupaten Pelalawan dan Kabupaten Indragiri Hulu yang tidak luput dari aktivitas konversi lahan untuk perkebunan kelapa sawit yang dilakukan secara illegal.

\section{Perumusan Masalah}

Ekspansi perkebunan kelapa sawit yang telah memasuki kawasan TNTN merupakan potensi besar terjadinya perubahan peruntukan lahan dan sumberdaya yang akan berdampak secara langsung terhadap perubahan bentang alam (landscape change). Berbagai permasalahan yang kemudian muncul adalah keberlangsungan atau kelestarian fungsi kawasan tersebut sebagai perlindungan keanekaragaman hayati dan perlindungan satwa langka seperti gajah dan harimau sumatera. Hilangnya tutupan hutan juga berdampak terhadap masyarakat dalam banyak aspek kehidupan sepertikebakaran hutan yang kemudian menyebabkan bencana susulan seperti asap, banjir, kekeringan dan hilangnya sumber penghidupan masyarakat lokal.

Persoalan lain adalah pembiaran munculnya pemukiman baru oleh pemerintah daerah dalam kawasan TNTN semakin mengancam keberlangsungan TNTN. Ini diperparah lemahnya pengawasan dan penegakan hukum oleh instansi terkait baik pemerintah daerah maupun pemerintah pusat. Perlindungan terhadap lahan yang belum terjamah budidaya perkebunan, termasuk kawasan hutan konservasi dan hutan lindung, lahan pertanian rakyat perlu dilakukan sehingga tidak dengan mudah menjadi perkebunan kelapa sawit. Jika tidak dikelola dengan baik, perluasan perkebunan kelapa sawit akan terus merusak hutan yang semestinya dilindungi. Secara global perubahan tersebut akan dapat menimbulkan perubahan struktur perekonomian secara lokal dan regional. Tujuan dari penelitian ini adalah untuk; 1) Menganalisis proses perubahan penggunaan lahan disekitar lanskap TNTN akibat ekspansi kelapa sawit, dan 2) Menganalisis sistem penghidupan masyarakat lokal sekitar kawasan TNTN.

\section{METODE PENELITIAN}

\section{Waktu dan Tempat Penelitian}

Penelitian ini dilaksanakan pada bulan Juli sampai Desember 2015, bertempat desa Lubuk Kembang bunga dan Desa Air Hitamkecamatan Ukui Kabupaten Pelalawan, Provinsi Riau. Penentuan lokasi penelitian ini ditentukan secara sengaja (purposive), dengan pertimbangan melihat laju deforestasi di Hutan Taman Nasional Teso Nilo yang demikian tinggi telah menimbulkan konflik sosial ekonomi dan ekologi dalam desa sekitar kawasan TNTN.

\section{Jenis Data dan Metode Pengambilan Sampel}

Jenis data yang digunakan dalam penelitian ini adalah data primer dan data sekunder. Data primer diperoleh melalui observasi langsung di lapangan melalui wawancara dengan instrument kuisioner kepada responden yang merupakan penduduk di wilayah studi. Jenis data primer yang dibutuhkan berupa data kepemilikan lahan atau luas lahan yang dimiliki, data pendapatan, serta data tentang input sumberdaya yang dimiliki baik sumberdaya manusia maupun sumberdaya alam.

\section{Metode Analisis data}

Untuk mencapai tujuan dari penelitian ini maka analisis data akan dilakukan dengan menggabungkan studiliteratur, petadanwawancaradenganinformankunci dandiskusidengan stakeholder yang terkait. Untuk dapat melihat sejauh mana hubunganantara pembangunan ekonomidan kualitas lingkungan, dalam persepsi lokal. Indikator yang digunakan adalah ekologi, ekonomi dan sosial ( Noordwijk, 2013).

\section{Gambaran Umum Lokasi Penelitian}

Menurut topografinya kawasan Taman Nasional Tesso Nilo merupakan daerah dataran rendah sampai berbukit. Dibeberapa tempat ditemukan areal dengan kemiringan kurang dari 2 persen. Ketinggian kawasan daripermukaan laut berkisar antara 50-175 $\mathrm{m}$ dpl. Jenis tanah yang terdapat di wilayah TNTN umumnya termasuk jenis Kandiudult dan Drystropets yang setara dengan jenis podsolik merah kuning dan kambisol. (Hardjowigeno, 2003 dalam BTNTN 2010).

Kawasan ini secara umum digolongkan sangat lembab dengan curah hujan tahunan yang berkisar antara $2.000-3.000 \mathrm{~mm}$. Secara keseluruhan curah hujannya sangat tinggi, curah hujan rata-rata perbulan dapat turun sebanyak $60 \mathrm{~mm}$, sedangkan rata-rata perhari pertahun bervariasi antara 120-150. Kondisi iklim ini dapat berubah seiring dengan keadaan ekstrim seperti kekeringan akibat adanya El-Nino. Kondisi ilkim yang lembab dan rapat akan banyak menggugurkan daun, sehingga banyak tumbuhan yang kekeringan dan mati. Kondisi inilah yang kerap memicu kebakaran hutan seperti yang kerap melanda kawasan ini seperti beberapa tahun belakangan ini. Kebakaran hutan akan menimbulkan asap yang akan menpengaruhi kesehatan manusia secara signifikan (Gillison, 2001).

Kawasan Taman nasional Tesso Nilo dan sekitarnya merupakan daerah tangkapan air bagi beberapa sungai, diantaranya : Sungai Tesso dibagian barat, Sungai Segati dibagian Utara, Sungai Nilo dibagian Timur. Ketiganya merupakan Sud DAS dari DAS Kampar, tepatnya diantara DAS Tesso dan DAS Nilo di Propinsi Riau. Menurut Gillison (2001) TNTN memilik keanekaragam species tumbuhan vascukar tertinggi didunia sebanyak 218 species. Dan belum ditemukan daerah lain di 
Dunia yang memiliki keanekaragaman tumbuhan seperti di Tessonilo.

\section{Kondisi Sosial Ekonomi dan Budaya Masyarakat Sekitar TNTN}

Kondisi masyarakat yang tinggal disekitar Kawasan Taman Nasional Tesso Nilo dipandang dari sudut sistem sosial tradisional masyarakat desa merujuk pada sistem kebathinan, dimana desa desa dibagi kedalam sistem perbathinan adat Melayu Petalangan, Gunung Sahilan, dan Logas. Namun keadaan ini mulai memudar, pada beberapa desa sistem organisasi sosialnya tidak lagi dikategorikan kedalam sistem organisasi sosial berbasis pendududk asli. Hal ini dijumpai pada sebagian besar desa bentukan baru melalui transmigrasi baik program pemerintah maupun swakarsa.

Struktur keluarga dalam masyarakat desa tempatan merupakan gabungan antara sistem patrilineal dengan sistem matrilineal. Pada masyarakat dengan sistem perbathinan, pengaruh sistem patrilineal agak lebih menonjol dibandingkan pada masyarakat desa desa yang menganut sistem kepenghuluan (BTNTN,2010).

Kondisi pendidikan masyarakat pada desa sekitar kawasan masih terbilang rendah, hal ini disebabkan oleh minimnya fasilitas pendidikan yang ada didesa desa sekitar TNTN serta jauhnya akses menuju fasilitas pendidikan. Kondisi perekonomian masyarakat yang masih rendah yang menyebabkan banyak anak anak yang putus sekolah. Masyarakat yang bermukim di sekitar taman nasional sebagian besar bekerja di sektor pertanian diikuti dengan sektor perdagangan dan jasa.

\section{Kondisi Desa Lubuk Kembang Bunga dan Desa Air Hitam}

Lokasi penelitian ini mengambil sampel di dua desa yang berbatasan langsung dengan Taman Nasional Tesso Nilo yaitu desa Lubuk Kembang Bunga dan Desa Air Hitam yang secara administratif termasuk kedalam Kecamatan Ukui, Kabupaten Pelalawan.

Jumlah penduduk desa Lubuk Kembang Bunga menurut data BPS (2014) berjumlah 5.655 jiwa dengan rincian 2.396 jiwa perempuan dan 3.259 laki-laki. Dengan luas wilayah $75 \mathrm{Km}^{2}$ desa Lubuk kembang bunga memiliki rata-rata kepadatan penduduk sebesar 75 jiwa $/ \mathrm{km}^{2}$ dengan jumlah KK sebesar 1658. Namun sebagian besar dari jumlah kepala keluarga ini merupakan masyarakat "Toro" yaitu kelompok perambah yang bermukim dikawasan perluasan Taman nasional Tesso Nilo dan mendaftar kependudukan di Desa Lubuk Kembang Bunga.

Dibandingkan dengan Desa Lubuk Kembang Bunga, penduduk yang bermukim di Desa Air hitam lebih beragam. Terdapat banyak pendatang yang berasal dari luar desa seperti Sumatra Utara, jawa dan lainnya. Jumlah penduduk desa ini sebanyak $573 \mathrm{KK}$ dengan rincian perempuan 1.020 jiwa, laki laki 1.166 jiwa dengan total 2.186 jiwa. Denga luas desa 49,25 $\mathrm{Km}^{2}$ dan tingkat kepadatan penduduk sebesar 44 jiwa $/ \mathrm{km}^{2}$.

\section{Karakteristik Responden}

Desa Lubuk Kembang Bunga dan Desa Air Hitam berada pada dataran rendah dimana selama ini masyarakat menanam karet sebagai tanaman utamanya. Dulunya masyarakat disini juga menanam padi ladang dan kemudian karet setelah karet

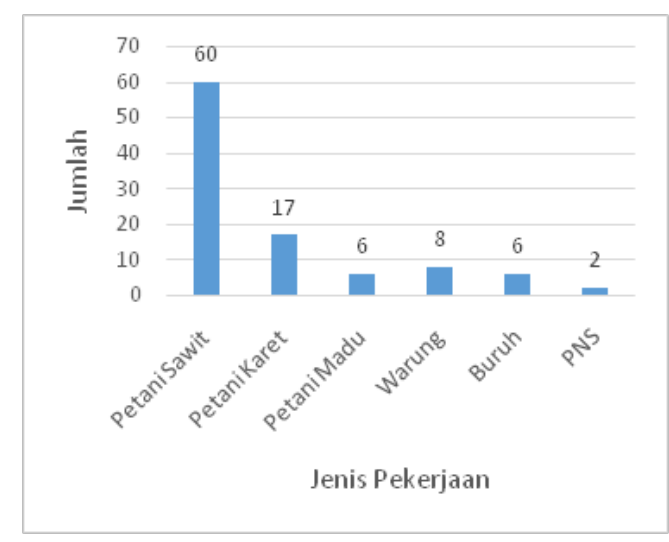

Gambar 3. Jenis Pekerjaan Responden di Desa Lubuk Kembang Bunga dan Desa Air Hitam Kecamatan Ukui Kabupaten Pelalawan Tahun 2015

umur dua atau tiga tahun mereka membuka ladang baru untuk bertanam padi serta memanfaatkan hasil hutan seperti madu, rotan, damar dan hewan buruan. Masyarakat yang bermukim didesa ini merupakan masyarakat asli yang merupakan suku melayu.

Penelitian ini mengambil responden yang merupakan penduduk asli masing-masing desa sebanyak 30 orang dengan total responden adalah 60 orang. Tingkat usia responden sangat beragam, dapat dilihat pada gambar 12. Responden tertinggi terdapat pada sebaran usia 41 sampai 50 tahun yaitu sebanyak 23 orang (38,3 persen), sedangkan responden yang terendah yaitu sebaran usia diatas 60 tahun sebanyak 2 orang atau 3,3 persen. Responden yang lainnya yaitu sebayaran usia 20 sampai 30 tahun sebanyak 5 orang ( 8,3 persen), responden sebaran usia 31 sampai 40 tahun sebanyak 19 orang $(31,7$ persen) dan sebaran usia 41 sampai 50 tahun sebanyak 11 orang (18,3 persen).

Tingkat pendidikan masyarakat desa di wilayah studi sangat beragam, namun masih tergolong rendah. Pada gambar 13 terlihat sebaran tingkat pendidikan responden. Dari 60 orang responden terdapat 14 orang (23,3 persen) tidak bersekolah, 23 orang (38,3 persen) tamatan sekolah dasar (SD) yang merupakan angka tertinggi, 15 orang (25 persen) tamatan sekolah tingkat pertama (SMP) dan 8 orang (13,3 persen) merupakan tamatan sekolah lanjutan (SMU). Rata rata anggota keluarga per KK adalah 5 orang. Mata pencaharian utama responden adalah berkebun sawit dan sebagian lagi memiliki kebun karet.

Jenis pekerjaan responden adalah petani, dengan mata pencaharian utama responden adalah berkebun sawit dan berkebun karet. Pada gambar 13 terlihat bahwa semua responden adalah petani yang memiliki perkebunan kelapa sawit dengan rata rata luas kebun 2,17 Ha. Sebagian dari petani sawit tersebut masih memiliki kebun karet dengan luas rata rata 0,34 ha. Sebagian lainya juga bekerja sebagai petani madu, yaitu mengambil madu dari pohon sialang sebanyak 6 orang, yang memiliki warung sebanyak 8 orang, sebagai buruh 6 orang dan 2 orang berprofesi sebagai guru dan tenaga administrasi dikelurahan.

\section{Perubahan Lanskap Ekologi Taman Nasional Tesso Nilo}

Taman Nasional Tesso Nilo yang pada mulanya merupakan lanskap hutan tropis dataran rendah yang memiliki keanekaragaman hayati yang sangat tinggi. Kawasan ini lebih dikenal sebagai Hutan Langgam oleh mansyarakat 


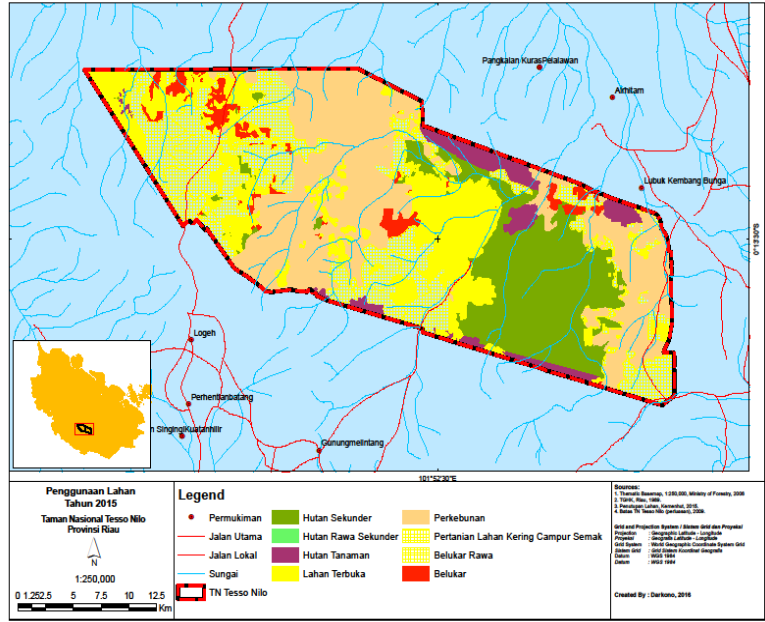

Gambar 4. Peta Penggunaan Lahan Taman Nasional Tesso Nilo Tahun 2015

setempat, memiliki luas 1,6 juta Ha pada tahun 1980-an. Perubahan ekologi lanskap hutan tersebut bermula dengan ditetapkannya kawasan sebagai Hutan Produksi Terbatas (HPT) yang pengelolaannya diberikan kepada swasta melalui Hak Penguasaan Hutan (HPH). Setelah ijin HPH berakhir peruntukan kawasan sebagian dirubah menjadi Hutan Tanaman Industri (HTI) guna memenuhi kebutuhan bahan baku industri bubur kertas dan produk kayu olahan lainnya.

Salah satu faktor yang mempercepat perubahan ekologi lanskap ini adalah dibukanya koridor ditengah hutan yang merupakan jalan yang dibangun oleh perusahaan pemegang HPH untuk aktivitas perusahaan tersebut. Dengan terbukanya jalan menuju hutan tersebut mempermudah akses menuju hutan sehingga mempercepat kerusakan hutan. Dampak paling besar adalah akses jalan tersebut membuat maraknya perambahan hasil hutan seperti kayu yang dilakukan oleh para perambah. Rusaknya hutan menyebabkan rusaknya habitat satwa sehingga angka gangguan serangan satwa seperti gajah yang memasuki pemukiman penduduk juga meningkat.

Setiap tahun gangguan konflik manusia dan satwa semakin meningkat sehingga pemerintah pada tahun 1984 mencadangkan Hutan Langgam sebagai habitat gajah. Menurut Gillison (2001) kawasan hutan TNTN merupakan salah satu kawasan penyangga populasi kunci dari gajah dan harimau sumatera yang kini terancam punah. Melalui Surat Keputusan no 255/Menhut-II/2004 tentang perubahan fungsi sebagian kawasan hutan produksi terbatas milik PT Inhutani IV menjadi taman nasional seluas 38.576 ha dan surat keputusan no 663/

\begin{tabular}{|c|c|}
\hline & 90,000 \\
\hline & 80,000 \\
\hline & 70,000 \\
\hline & 60,000 \\
\hline & 50,000 \\
\hline & 40,000 \\
\hline & 30,000 \\
\hline 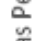 & 20,000 \\
\hline & 10,000 \\
\hline
\end{tabular}
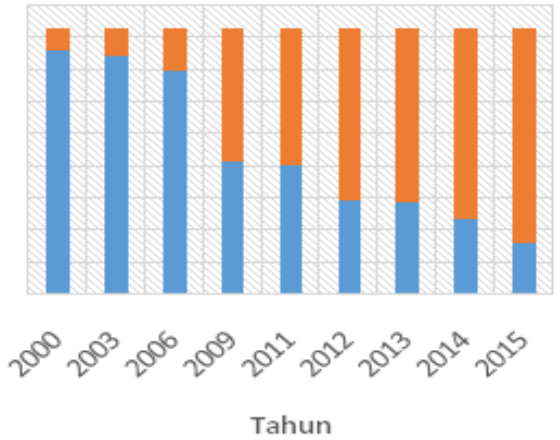

- Hutan Non Hutan

Gambar 5. Perubahan Tutupan Hutan TNTN dari tahun 2000 -2015
Menhut-II/2009 tentang perubahan fungsi sebagian kawasan hutan produksi terbatas kelompok hutan tesso nilo seluas 44.492 ha sehingga total keseluruhan Taman Nasional Tesso Nilo adalah 83.068 ha.

Tingginya nilai ekonomi dari kelapa sawit mendorong masyarakat melakukan ekspansi kedalam kawasan hutan sehingga mengancam keberlangsungan hutan. Hal ini terjadi pada kawasan konservasi Taman Nasional Tesso Nilo. Luas tutupan hutan Taman Nasional Tesso Nilo setiap tahunnya terus mengalami penurunan, dengan luas TNTN pada tahun 2005 seluas $70.553,56$ ha hingga tersisa $18.043,71$ ha pada tahun 2015. Dalam kurun waktu 10 tahun 52.509,65 ha tutupan hutan kawasan Taman Nasional Tesso Nilo telah berubah fungsi dan mengalami degradasi. Perubahan fungsi kawasan tersebut sebagian besar akibat adanya ekspansi perkebunan kelapa sawit di dalam kawasan, serta pembukaan pemukiman baru (WWF,2013)

Luas hutan Tesso Nilo pada tahun 2015 yang telah mengalami perubahan sekitar 80,76 persen menjadi non hutan. Ekspansi perkebunan kelapa sawit kedalam TNTN telah merubah TNTN menjadi perkebunan sawit illegal. Perubahan tutupan hutan terbesar terjadi dalam kurun waktu 2006 sampai 2009 , dimana seluas 28.120 ha hutan telah berubah menjadi perkebunan kelapa sawit dan pemukiman penduduk. Bila hal ini terus dibiarkan maka seluruh kawasan TNTN akan berubah menjadi perkebunan kelapa sawit dan seluruh stawa yang ada disana akan mengalami kepunahan.Berdasarkan pengamatan dilapangan masyarakat merasa bahwa batas kawasan konseravsi dan desa mereka tidak jelas. Ini disebabkan oleh kurang jelasnya tata batas TNTN yang membuat masyarakat ragu akan keberadaan lahan mereka

Perubahan ekologi TNTN akibat terjadinya ekspansi kelapa sawit telah menyebabkan menurunnya fungsi kawasan sebagai kawasan konservasi. Hutan yang tersisa saat ini hanya sekitar 20 persen sehingga merupaka ancaman bagi keberlangsungan kehidupan satwa langka seperti gajah dan harimua sumatra. Perubahan ekologi lanskap TNTN juga memicu konflik antara manusia dan satwa, penurunnya persediaan air, dan bencana kebakaran yang menyebabkan bencana asap terjadi hampir setiap tahun.

\section{Dinamika Okupasi Kawasan: Analisis Web of Power dan Transisi Penguasaan Kawasan}

Migrasi merupakan suatu bentuk respon dari orang-orang dengan alasan untuk meningkatkan kesejahteraan hidupnya. Migrasi yang menuju perkotaan disebabkan oleh adanya faktor daya tarik perkotaan serta adanya faktor-faktor pendorong dari kawasan pedesaan, walaupun urban tersebut tidak mampu menampung kedatangan penduduk yang datang dari berbagai daerah lainnya (Rustiadi, 2009). Namun dalam kasus migrasi kedalam taman nasional terjadi sebaliknya, dimana faktorfaktor penarik berupa sumber daya alam telah menyebabkan tingginya migrasi ke wilayah ini.

Tingginya angka perubahan tutupan hutan akibat ekspansi kelapa sawit kedalam kawasan telah menyebabkan TNTN mengalami degradasi yang sangat tinggi sebagai konsekuensi alih fungsi lahan. Konservi lahan disuatu wilayah biasanya terjadi searah dan tidak dapat kembali. Seperti lahan hutan yang telah dikonversi menjadi lahan pertanian, lahan perkebunan atau pemukiman. Apabila konversi ini terjadi secara besar-besaran seperti yang terjadi di TNTN akan berakibat buruk bagi lingkungan, inefisiensi ekonomi serta 
masalah pemerataan dan keadilan dalam pengelolaan sumber daya alam.

Sebagai sebuah kawasan konservasi maka kegiatan pengembangan perkebunan kelapa sawit di dalam kawasan merupakan kegiatan illegal. Demikian pula dengan hadirnya pemukiman pemukiman baru yang dibentuk oleh para perambah kawasan. WWF (2013) menyatakan bahwa sebaran kebun sawit di dalam TNTN berdasarkan pola kepemilikannya dilakukan secara individu dan kelompok. Modal pengembangan dan pengelolaan kebun dilakukan secara swadaya oleh masing-masing pemilik. Sementara kebun yang dikelola secara kelompok, modalnya ditanggung bersama oleh anggota kelompok. Namun juga ditemukan adanya indikasi kelompok yang memperoleh modal dari perusahaan. Kebun sawit di dalam kawasan hutan Tesso Nilo dikuasai dan dikelola oleh individu dan kelompok. Teridentifikasi 524 orang mendominasi 72 persen ( 26.298 ha) dari total area perambahan yang telah dikonversi menjadi perkebuan kelapa sawit (36.353 ha), sementara sisanya dikelola oleh 20 kelompok. Rata-rata kebun yang dimiliki oleh individual adalah 50 ha, jauh lebih besar dari rata-rata kebun yang dimiliki oleh petani.

Menurut masyarakat setempat Taman Nasional Tesso Nilo yang diperluas pada tahun 2009 adalah bekas HPH atau hak pengusahaan hutan yang sudah memiliki akses jalan masuk sehingga memudahkan untuk masuk kedalam hutan. Kawasan ini memang sudah ditempati oleh masyarakat jauh sebelum ditetapkan sebagai taman nasional.

\begin{abstract}
"Saya sudah tinggal didalam sini sejak tahun 2004 dan sudah punya kebun sawit. Kebun sawit saya sudah panen. Penghasilan saya dan keluarga cukup besar dari hasil panen sawit ini. Saya sudah membeli tanah ini dari pemangku adat setempat, saya memiliki suratnya. Kalau kami harus keluar dari sini bagaimana dengan kebun kami?" (Bapak SBG, 40 Tahun).
\end{abstract}

Akses merupakan kemampuan untuk memperoleh manfaat dari sesuatu (the ability toderive benefit from things). Bila dilihat dari pernyataan informan tersebut terlihat bahwan ia memperoleh lahan melalui oknum pemegang adat setempat. Akses diperoleh melalui kekuasaan yang dipegang oleh seseorang. Akses dalam pengertian ini mengandung makna sekumpulan kekuasaan (bundle of powers)yang dimanfaatkan untuk memperoleh akses terhadap sumberdaya (Ribot dan Peluso, 2003). Lebih lanjut Ribot dan Peluso (2003) mengatakan bahwa akes dalam kekuasaan diartikan sebagai sesuatu yang terdiri atas elemen-elemen material, budaya dan ekonomi politik yang terhimpun sedemikian rupa sehingga membentuk bundle kekuasaan (bundle of powers) dan jaringan kepentingan (web of powers) yang kemudian menjadi penentu akses ke akses sumber daya.

Ekspansi perkebunan kelapa sawit secara illegal ke kawasan TNTN dilakukan oleh pendatang dari luar daerah yang membuka kebun didalam kawasan TNTN. Kemudahan untuk mendapat akes membuka lahan menjadi pendorong utama semakin banyaknya perambah. Ekspansi perkebunan kelapa sawit ini telah terjadi secara sangat lama tanpa ada tindakan yang tegas dari aparat hukum setempat. Berdasarkan informasi yang diperoleh dari BTNTN dan WWF diketahui bahwa ekspansi perkebunan kelapa sawit kedalam TNTN bukan dilakukan oleh masyarakat adat atau lokal, melainkan oleh para pendatang yang dari luar. Namun saat ini para pendatang ini telah membentuk dusun-dusun baru didalam kawasan, dan mereka membangun kesatuan masyarakat hukum berbentuk dusun dibawah hirarki administrasi desa adat/lokal setempat. Hal ini yang kemudian menjustifikasi klaim bahwa perambah merupakan masyarakat lokal atau masyarakat adat setempat. Berdasarkan wawancara dengan masyarakat lokal mereka merasa sangat dirugikan dengan adanya masalah tersebut. Seorang informan dari desa Lubuk Kembang bunga mengatakan bahwa;

"perambahan yang dilakukan didalam Taman
Nasional dilakukan oleh orang luar, bukan kami
penduduk desa ini, kami hanya dirugikan saja
dengan adanya berita di luar yang mengatakan
bahwa kami warga desalah yang telah merusak
hutan, padahal kami warga asli tidak berani
masuk, Tapi orang luar bisa masuk merambah
namun dibiarkan saja. Kami juga mau masuk
kalau memang kondisinya seperti itu”(Bapak
JD, 34 Thn).

Masyarakat lokal tidak ikut melakukan perambahan kedalam Taman Nasional karena mereka mengetahui bahwa hutan yang berada di sekitar desa mereka merupakan taman nasional yang dilindungi oleh pemerintah, sehingga masyarakat takut untuk membuka lahan di dalam hutan seperti yang dilakukan oleh para pendatang. Pada awal penetapan sebagai taman nasional, untuk mengamankan kawasan TNTN Balai KSDA dan WWF meluncurkan program kerjasama patroli pengamanan kawasan. Program ini melibatkan masyarakat sekitar kawasan untuk ikut aktif menjaga dan menanggulangi berbagai bentuk kegiatan yang menjadi ancaman bagi kawasan dan satwa tang dilindungi.

Namun dengan semakin maraknya perambahan didalam kawasan menimbulkan tanda tanya bagi masyarakat tentang status hutan saat ini. Masyarakat melihat bahwa kebun sawit yang dimiliki oleh masyarakat yang tinggal didalam luas bahkan ada yang memiliki hingga puluhan hektar. Kecemburuna sosial yang dirasakan oleh masyarakat adalah mereka memiliki keterbatasan lahan untuk memperluas perkebunan kelapa sawit milik masyarakat karena sebagian wilayah desa merupakan bagian dari taman nasional, sehingga masyarakat kemudian mengkonversi lahan apa saja yang mereka miliki seperti pekarangan rumah, ladang dan kebun karet mereka menjadi perkebunan kelapa sawit.

\section{Perubahan Sistem Nafkah Masyarakat Lokal sekitar Lanskap TNTN}

Perkembangan industri kelapa sawit di Propinsi Riau yang sangat pesat menarik minat masyarakat untuk menanam kelapa sawit. Hal ini juga terjadi di desa-desa sekitar Taman Nasional. Ekspansi kelapa sawit yang sangat besar telah membuat banyak petani mengkonversi hampir seluruh lahan yang mereka miliki menjadi sawit. Berdasarkan data dari Kecamatan Ukui dalam Angka diketahui bahwa konversi lahan terbesar terjadi di tahun 2012 dimana potensi lahan sawah ditahun 2011 seluas 5.128 ha menjadi tinggal 133 ha. Potensi lahan ini pun dalam realisasi tanam berdasarkan data dari kecamatan ukui dalam angka (2014) bahwa yang berproduksi hanya perkebunan saja sementara sawah, ladang, dan lainnya tidak ada produksi pertanian yang dihasilkan.

Kecamatan Ukui memiliki potensi lahan yang cukup beragam untuk dikembangkan seperti ada potensi lahan untuk sawah, ladang, tegalan, pekarangan dan lainnya. Namun masyarakat 
lebih memilih untuk menanam kelapa sawit dibandingkan dengan tanaman pertanian lainnya. Konversi lahan yang sangat tinggi terjadi ditahun 2012 karena masyarakat ingin memperluas perkebunan kelapa sawit mereka namun keterbatatasan lahan menjadi kendala, sehingga untuk mencapai tujuan tersebut maka masyarakat melakukan konversi lahan apa saja yang mereka miliki seperti mengkonversi lahan pekarangan rumah mereka menjadi ditanami sawit. Tingginya nilai ekonomi kelapa sawit menjadi pemicu perubahan sistem nafkah pada masyarakat lokal.

\section{Struktur Nafkah Rumah Tangga Masyarakat Lokal Sekitar Lanskap TNTN.}

Struktur nafkah adalah komposisi pendapatan rumah tangga petani dari berbagai aktivitas nafkah yang dilakukan oleh seluruh anggota rumah tangga dalam kurun waktu satu tahun. Struktur nafkah dalam penelitian ini dibagi menjadi 3 sumber, yaitu of farm, off farm dan non farm. Dalam penelitian ini rumah tangga petani merupakan penduduk asli atau masyarakat lokal Desa Lubuk Kembang Bunga dan Desa Air Hitam. Umumnya masyarakat desa ini memiliki perkebunan karet dan sawit sehingga sumber nafkah on farm adalah sumber nafkah yang diperoleh oleh petani dari hasil perkebunan kelapa sawit dan perkebunan karet. Sementara off farm adalah kegiatan yang dilakukan oleh petani dengan memanfaatkan hasil hutan seperti mengambil madu hutan. Sedangkan sumber nafkah non farm diperoleh dari usaha jasa, dagang, upah, bantuan dan lainnya.

Sektor on farm tetap merupakan sumber utama pendapatan rumah tangga petani (gambar 5). Pendapatan rumah tangga petani pertahun untuk Desa Lubuk Kembang Bunga dan Desa Air Hitam diperoleh dari kegiatan on Farm yaitu dengan rata rata pendapatan pertahun sebesar Rp 15.174.800 atau sekitar 80 persen dari total pendapatan per tahun. Sementara Desa Air Hitam memiliki pendapatan rata-rata juga terbesar dari

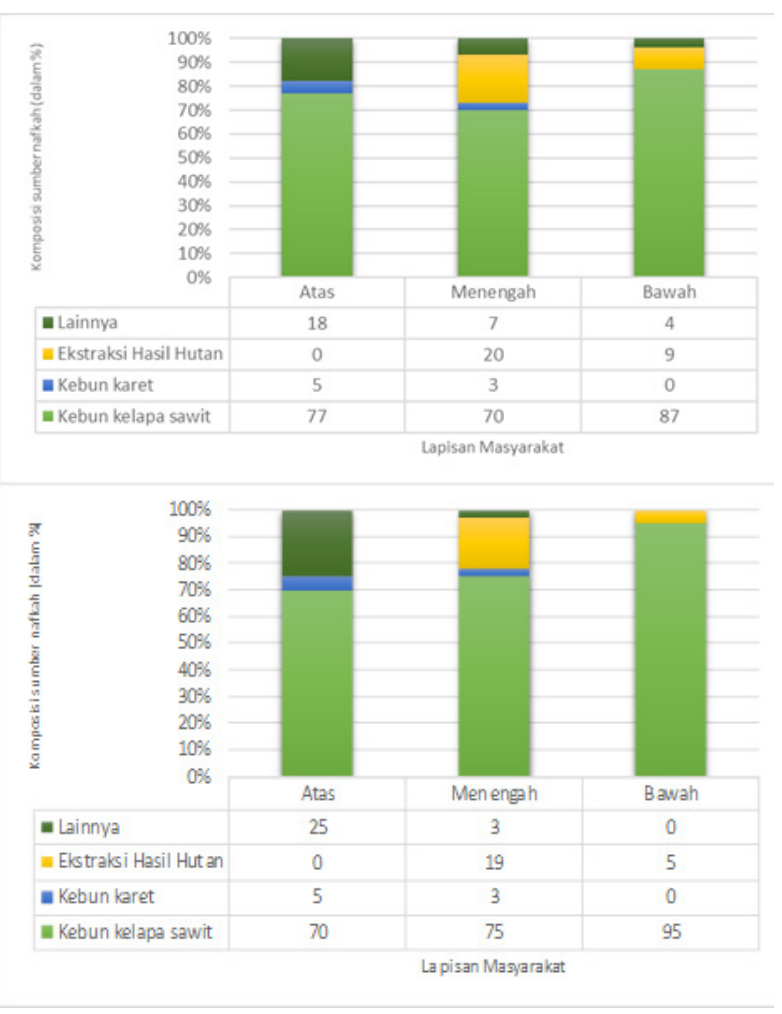

Gambar 6. Struktur Nafkah Rumah Tangga Petani Pertahun Desa Lubuk Kembang Bunga dan Desa Air Hitam Kecamatan Ukui Kabupaten Pelalawan tahun 2015

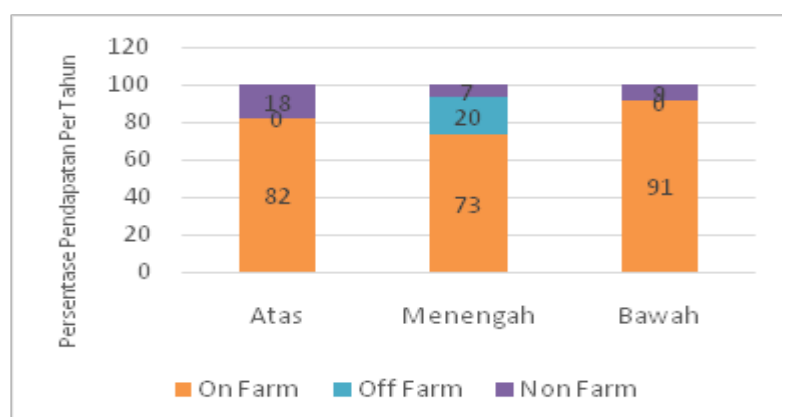

Gambar 7. Struktur Pendapatan Masyarakat Desa

Lubuk Kembang Bunga Tahun 2015

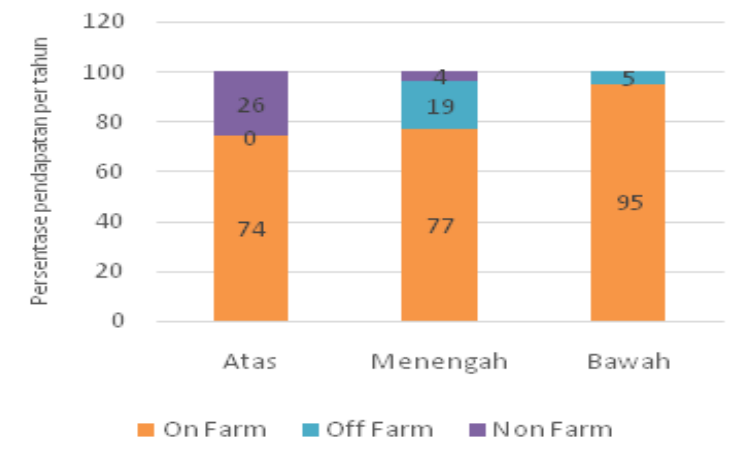

Gambar 8. Struktur Pendapatan Masyarakat Desa Air Hitam Tahun 2015

kegiatan On Farm yaitu sebesar Rp 19.620.000 atau sekitar 82 persen. Kegiatan Off Farm untuk kedua desa sangat kecil, jika dilihat dari pendapatan yang berasal dari kegiatan Off Farm maka Desa Lubuk Kembang Bunga hanya sekitar Rp 1.825.000 per tahun atau 10 persen sedangkan Desa Air Hitam sebesar Rp 1.883 .333 pertahun atau hanya 8 persen. Kontribusi pendapatan dari kegiatan Non Farm untuk masing masing desa adalah Rp 2.060.000 atau 10 persen Desa Lubuk Kembang Bunga dan Rp 2.413.333 atau 10 persen Desa Air Hitam.

Komposisi struktur nafkah masyarakat lokal kedua desa ini masih sangat bergantung terhadap hasil perkebunan sawit, dimana pendapatan terbesar yang mereka peroleh didapat dari hasil perkebunan kelapa sawit. Sementara kontribusi dari kegiatan off farm dan non farm sangat kecil dengan nilai dibawah sepuluh persen. Dalam kegiatan on farm masyarakat Desa Lubuk Kembang Bunga memiliki perkebunan kelapa sawit dengan luas rata-rata 2,1 ha sementara kebun karet dengan luas rata rata 0,8 ha. Sedangkan Desa Air Hitam memiliki perkebunan kelapa sawit dengan luas rata-rata 2,23 ha sementara kebun karet dengan luas rata rata 0,08 ha.

Perkebunan kelapa sawit menjadi dominan didalam menopang sistem penghidupan rumah tangga di kedua desa. Sehingga terjadi proses pergeseran struktur nafkah yang sebelumnya beragam dari hasil karet, berladang, berburu, dan memanfaatkan hasil hutan menjadi struktur nafkah yang relatif homogen dengan didominasi oleh kelapa sawit. Akibat tingginya dominansi perkebunan kelapa sawit menyebabkan struktur ekonomi non sawit menjadi tidak berkembang, dimana heterogenitas nafkah rendah sehingga membuat masyarakat dikedua desa sangat rentan sehingga resiko terhadap krisis sangat tinggi dengan resiliensi nafkah yang rendah.

Hadirnya perkebunan kelapa sawit skala besar dan berdirinya pabrik pabrik pengolahan disekitar desa telah mengubah sistem nafkah pedesaan secara fundamental. Sistem nafkah 
didominasi dari satu sumber nafkah yaitu dari perkebunan kelapa sawit. Masyarakat bahkan rela mengkonversi lahan yang sedianya untuk tanaman pangan menjadi perkebunan kelapa sawit, bahkan konversi untuk perkebunan kelapa sawit juga dilakukan pada lahan pekarangan rumah.Pola nafkah masyarakat sekitar kawasan berubah menjadi cenderung homogen dengan satu sumber nafkah yaitu dari perkebunan kelapa sawit. Ini menyebabkan masyarakat menjadi rentan terhadap krisis ketika harga kelapa sawit menurun.

\section{Ekspansi Kelapa Sawit dan Kerentanan Ekonomi Rumah Tangga Petani}

Kemiskinan didefenisikan sebagai suatu keadaan dimana tingkat tingkat pendapataan seseorang tidak dapat menyebabkan dirinya mengikuti tata nilai dan norma-norma yang berlaku dimasyarakat (Rustiadi, 2009). Beberapa tolak ukur mengenai kemiskinan banyak dikemukan oleh para pakar. World Bank juga menetapkan standar garis kemiskinan, dimana garis kemiskinan yang ditentukan oleh world bank adalah USD \$2 pendapatan per kapitan per hari atau senilai Rp $27.000^{1}$ per kapita per hari, maka apabila pendapatan seseorang berada dibawah Rp 27.000 per hari maka akan termasuk dalam golongan miskin. Kabupaten pelalawan Propinsi Riau juga mengeluarkan angka standar garis kemiskinan kabupaten. Berdasarkan angka yang dikeluarkan oleh BPS Pelalawan dalam Pelalawan dalam angka 2014 bahwa angka poverty line untuk Kabupaten Pelalawan adalah Rp 429.452. atau Rp 14.119 perhari perkapita.

Hampir seluruh penduduk desa Lubuk Kembang Bunga dan desa Air hitam berada dibawah standar kemiskinan menurut World Bank yaitu Rp 27.000 per kapita. Namun bila dibandingakn dengan standar kemiskinan dari Kabupaten Pelalawan maka sebagian besar masyarakat desa masih berada diatas garis kemiskinan. Kecuali lapisan bawah di desa lubuk kembang Bunga yang memiliki pendapatan per kapita hanya sebesar Rp 8.072 per kapita.

Terjadinya penurunan pendapatan yang sangat besar ini disebabkan oleh adanya penurunan harga kelapa sawit sehingga masyarakat kehilangan pendapatan sangat besar dibandingkan dengan pendapatan pada tahun sebelumnya. Hai ini nerupakan gambaran bagaimana perubahan ekonomi global bisa berakibat terhadap masyarakat kecil yang mengantungkan hidupnya dari perkebunan kelapa sawit. Ketika harga pasaran kelapa sawit tinggi maka mereka akan merasakan dampaknya dengan besarnya penerimaan yang diperoleh, namun begitu harga sawit turun maka pendapatan mereka juga akan

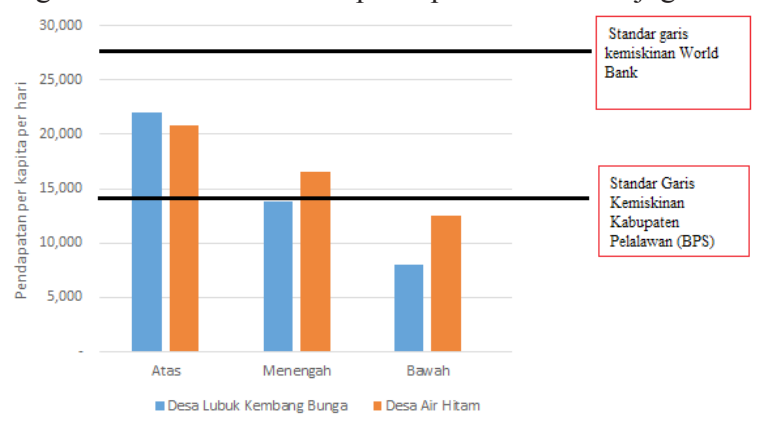

Gambar 9. Pendapatan Perkapita Masyarakat menurut Lapisan di Desa Lubuk Kembang Bunga dan Desa Air Hitam Kecamatan Ukui Tahun 2015

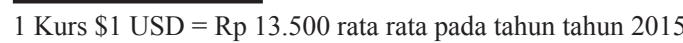

langsung berkurang. Gejolak harga produk sawit ini pada akhirnya akan mempengaruhi pola konsumsi masyarakat desa. Tingginya ketergantungan terhadap pasokan pangan dari luar akan menyulitkan masyarakat ketika pendapatan mereka mengalami penurunan.

Kemampuan menyimpan merupakan kemampuan yang dimiliki oleh rumah tangga untuk dapat menabung atau menyimpan uangnya. Kemampuan menyimpan ini diukur melalui pendapatan yang diterima pertahun dikurangi dengan pengeluaran rumah tangga pertahun. Dari hasil tersebut, apabila hasil pengurangan tersebut besar maka tingkat kemampuan menyimpan yang dimiliki oleh keluarga tersebut tinggi namun apabila hasilnya kecil atau minus maka tingkat kemampuan menyimpanyang dimiliki oleh keluarga tersebut rendah.

Masyarakat lapisan atas desa lubuk kembang bunga memiliki tingkat kemampuan menyimpan yang cukup tinggi sementara lapisan menengah dan bawah tingkat kemampuan menyimpanrendah. Demikian juga dengan desa Air hitam, masyarakat golongan atas memiliki tingkat kemampuan menyimpanyang tinggi dibandingkan dengan kedua lapisan lainnya.Semakin tinggi tingkat lapisan pendapatan masyarakat maka akan semakin besar tingkat kemampuan menyimpanyang mereka miliki. Untuk lapisan atas desa lubuk kembang bunga lapisan atas mampu menyimpan rata rata pertahun sebesar Rp 8.331.429 sementara untuk desa air hitam golongan atas mampu menyimpan sebesar Rp 4.926.667. per tahunnya.Angka ini cukup besar dibandingkan dengan dua lapisan dibawahnya. Lapisan Menengah desa Air Hitam masih memiliki saving capacity sebesar Rp 662.500 per tahun. Tidak demikian dengan golongan bawah kedua desa ini yang justru mengalami kekurangan dimana pengeluaran jauh lebih besar daripada pendapatan yang mereka terima. Rumah tangga yang memiliki simpanan yang cukup besar akan lebih mampu bertahan dalam menghadapi krisis kala adanya penurunan pendapatan.

\section{KESIMPULAN DAN SARAN}

\section{Kesimpulan}

1. Ekspansi perkebunan kelapa sawit telah menyebabkan perubahan lanksap ekologi TNTN dimana hutan menjadi terdegrasi secara masif, ditunjang dengan tingginya ekspansi kepala sawit kedalam kawasan maka ancaman terhadap keberlangsungan kawasan sebagai kawasan konservasi semakin tinggi.

2. Perubahan lanskap ekologi juga telah menyebabkan perubahan sistem penghidupan masyarakat sekitar taman nasional. Tingginya pendapatan yang diperoleh dari sawit menggambarkan tingginya ketergantungan masyarakat terhadapa komoditas ini

3. Tingginya ketergantungan masyarakat terhadap sawit dapat menyebabkan tingginya kerentanan nafkah rumah tangga masyarakat karena hanya berasal dari satu sumber nafkah, sehingga bila terjadi gejolak harga sawit dapat menyebabkan masyarakat kehilangan banyak pendapatan seperti yang terjadi saat ini.

\section{Saran}

Keberlanjutan pengembangan wilayah disekitar kawasan konservasi memerlukan pengelolaan kawasan yang lebih seimbang antara optimalisasi fungsi ekologis dan fungsi sosial ekonomi bagi masyarakat sekitar hutan sehingga kerusakan 
ekologis hutan akibat tindakan ekspansi ini bisa diatasi dan potensi konflik antara pihak perkebunan kelapa sawit dan pertanian tanaman pangan kedepan dapat diantisipasi sehingga tidak terjadi kerentanan ekonomi rumah tangga petani.

\section{DAFTAR PUSTAKA}

BTNTN (Balai Taman Nasional TessoNilo). 2010. BukuZonasi Taman nasionalTessoNilo. Riau : BTNTN.

Biro Pusat Statistik (BPS). 2014. Kecamatan Ukui dalam Angka. BPS Riau.

Colchhester M, Sophie Chao, Jonas Dallinger, HEP Sokharrano, Vo Thai Dan, Jo Villanueva. 2007. Promised Land. Palm Oil And Land Acquisition in Indonesia : Implications for Local Communities and Indegenous Peoples. FPP and SW.Bogor.

Desa Air Hitam. 2015. Monografi Desa Air Hitam. Pelalawan. Desa Air Hitam

Desa Lubuk Kembang Bunga .2015. Monografi Desa Lubuk Kembang Bunga. Pelalawan. Desa Lubuk kembang Bunga.

Dharmawan AH. 2007. Sistem Penghidupan dan nafkah Pedesaan. Pandangan Sosiologi nafkah (livelihood sosiology) Mahzab Barat dan Mahzab Bogor. Sodality: Jurnal transdisiplinsosiologi, komunikasi dan ekologi manusia. 01(2). Agustus. 2007
Dharmawan A.H., Putri E.I.K., MardianingsihD.I., Tarigan, H., Thirtawati, 2014. Mekanisme adaptasi dan resiliensi Masyarakat Petani Terhadap Variabilitas Iklim: Studi kasus masyarakatbtani di Jawa Barat dan Sumatra Selatan, Bogor [ID]: Pusat Studi Pembangunan Pertanian dan Pedesaan LPPM, IPB.

Gillison, AN. 2011. Vegetation Survey and Habitats Asessment of the Tesso Nilo Forest Complek. Biodiversity Survey In Tesso Nilo Sumatra Indonesia. WWF US

Lindenmayer. 2010. Landscape change and the science of biodiversity conservation in tropical forest : A View from the temperate world. Biological Conservation 143 (2010) 2405-2411. Elsevier. Diaksestanggal 5 desember 2014

NoordwijkMN,. Lusiana B.,Leimona B., Sonya D., Wulandari D. 2013. Negotiation-Support Toolkit for Learning Lanscape. World Agroforestry Centre. Indonesia

Pusat Data danSistemInformasiPertanian. No 01/01/I,7 Januari 2013. DepartemenPertanian.Jakarta

Ribot Jesse C and Nancy Lee Peluso. 2013. A Theori of Accsess. Rural Sosiology 08 (2).2003. pp 153-181. Diakses tanggal 15 Februari 2016.

Rustiadi E, Sunsun S, Dyah R Panuju .2011. Perencanaan dan Pengembangan Wilayah. Crespent Press. Jakarta. Yayasan Obor Indonesia.

WWF Riau. 2013. Sawit Dari Taman Nasional. Menelusuri TBS sawit illegal di Riau Sumatra. 